\title{
METODE DAKWAH KEPADA PENGUASA (STUDI ANALISIS PENDEKATAN ETIKA DAKWAH)
}

\author{
MASTORI \\ Sekolah Tinggi Agama Islam -Perguruan Tinggi Dakwah Islam Indonesia \\ (STAI PTDII) \\ mastory87@gmail.com
}

\begin{abstract}
This article discusses the method of da'wah to the authorities. This paper serves to inform Islamic leaders or activists about how to preach to the authorities, through mind or space olny to deny the tyranny of the ruler.
\end{abstract}

Keywords : Penguasa, Dakwah, Etika dakwah.

\section{PENDAHULUAN}

Dalam khazanah pemikiran dan hukum Islam, dakwah merupakan sebuah kewajiban syariat yang dibebankan kepada umat Islam. Pembebanan kewajiban ini dimaksudkan supaya sifat atau karakter ajaran Islam yang rahmatan lil'alamin dapat dirasakan oleh segenap manusia dan alam. Artinya, tanpa melalui kegiatan dakwah, kerahmatan Islam sulit untuk diwujudkan. Hal ini disebabkan kerahmatan Islam akan terlihat apabila syariat agama Islam ini dapat direalisasikan atau diamalkan secara individu, keluarga dan kolektif (masyarakat/Negara).

Lebih dari itu, dakwah diupayakan agar umat Islam memiliki izzah dan kekuatan. Sulit dibayangkan kekuatan Islam dapat diwujudkan tanpa adanya usaha- usaha dakwah yang ditujukan untuk menyebarkan dan memperluas pengaruh Islam sebagai diin ditengah-tengah masyarakat. Dengan kata lain, tanpa melalui kegiatan dakwah, Islam tidak mungkin menjadi kekuatan, tidak mungkin tersebar luas, tidak mungkin dapat dijaga dan tidak mungkin pula hujjah Allah isa ditegakan atas para makhluk Nya (Mahmud, 2002)

Dalam Islam, dakwah harus dijalankan sesuai dengan koridor dan aturan yang telah ditetapkan dalam al-Qur'an dan sunnah. Dalam Al-Quran surat An-Nahl:125, Allah menjelaskan :

"Serulah (manusia) kepada jalan Tuhan-mu dengan hikmah dan pelajaran yang baik dan bantahlah mereka dengan cara yang baik. Sesungguhnya Tuhanmu Dialah 
yang lebih mengetahui tentang siapa yang tersesat dari jalan-Nya dan Dialah yang lebih mengetahui orangorang yang mendapat petunjuk" (QS An-Nahl:125)

Menurut (Moh. Ali Aziz, 2004), dalam surat An-Nahl ayat 125 diatas mengandung tiga metode dakwah yang te rkenal, yaitu dengan Hikmah (Ghafur, 2014), Mauidhah Hasanah (Ya'cub, 2009), dan Mujadalah (Maqfiroh, 2014). Karena dakwah sangat identik dengan penggunaan bahasa maka ketiga metode dakwah ini tentu harus berjalan dengan bahasa yang baik.

Selain itu, tiga macam metode dakwah tersebut harus dikemas dengan cara dan metode yang tepat dan relevan. Karena dakwah harus tampil secara aktual, faktual dan kontekstual. Aktual berarti memecahkan masalah yang hangat di tengah masyarakat. Faktual berarti konkret dan nyata, serta kontekstual berarti relevan dan menyangkut problema yang sedang dihadapi oleh masyarakat (Suparta, 2009).

Salah satu objek dakwah yang sering luput dari pembicaraan akademis adalah penguasa/pemerintah. Keluputan ini menyebabkan terjadinya 'pembiaran' terhadap kedzaliman dan penyimpangan penguasa dari norma-norma keadilan yang diajarkan oleh syariat Islam. Akibatnya, penguasa yang seharusnya membawa kemaslahatan bagi rakyat yang dipimpinnya malah justru mendatangkan kemudharatan.

Lebih jauh, da'i atau ulama yang seharusnya berada pada garda terdepan dalam menyampaikan dakwah kepada penguasa, sebagian mereka justru menjadi 'tukang stempel' kebijakan penguasa dzalim. $\mathrm{Hal}$ ini menyebabkan kaburnya nilai dan norma ditengah-tengah masyarakat. Antara yang haq dan bathil menjadi sulit dibedakan oleh karena kebathilan itu telah diberi stempel 'baik' oleh da'i atau ulama nakal tadi. Atas dasar itu, imam Ghazali kemudian memberikan peringatan tentang bahaya da'i atau ulama dunia agar umat berhati-hati dan berupaya untuk mengenali karakteristik mereka. Menurut Al Ghazali, ulama dunia adalah ulama jahat yang tujuan ilmunya untuk kemewahan dunia dan sebagai jembatan untuk mendapatkan kemuliaan dan kedudukan dihadapan pemilik-pemilik dunia (Ghazali, 1997). Sebagai contoh pada pertengahan akhir 2016 lalu, kaum muslimin Indonesia dihebohkan oleh kasus penistaan kitab suci al-Qur'an yang dilakukan oleh Gubernur DKI Jakarta. Alih-alih menasehati sang Gubernur, beberapa ulama justru melakukan pembelaan.

Fenomena lain yang terjadi terkait dengan dakwah kepada penguasa adalah adanya perbedaan-perbedaan prinsip bagaimana seharusnya melakukan dakwah kepada mereka. Mengingat penguasa merupakan orang yang memiliki kedudukan terhormat ditengah masyarakat sehingga mengharuskan adanya metode dakwah yang berbeda dengan mempertimbangkan aspek psikologis, sosiologis dan antropologis penguasa itu sendiri.

Berpijak pada latar belakang diatas, dapat dirumuskan beberapa pertanyaan sebagai berikut. Pertama, bagaimana kedudukan penguasa didalam Islam? Kedua, bagaimana metode dakwah kepada 
Al-Fikra: Jurnal IImiah Keislaman, Vol. 17, No. 2, Juli-Desember, 2018 (324338)

$\begin{array}{llr}\text { penguasa. } & \begin{array}{l}\text { Ketiga, } \\ \text { dakwah }\end{array} \\ \text { meninggalkan } \\ \text { penguasa. }\end{array}$

\section{PENGERTIAN METODE DAKWAH}

Secara bahasa, metode terambil dari bahasa Yunani yaitu dari kata methodos, yang merupakan gabungan dari kata meta yang berarti melalui, mengikuti dan kata hodos berarti jalan atau cara. Sedangkan dalam bahasa Jerman, metode berasal dari akar kata methodica yang berarti ajaran tentang metode. Sementara dalam bahasa Arab metode disebut thariq, atau thariqah yang berarti jalan atau cara (Munawir, 1984). Kata-kata tersebut identik dengan kata al Ushlub walaupun secara syara' antara ushlub dan thoriqah dan uslub memiliki perbedaan. Thoriqah adalah jalan atau cara yang pasti dan tidak terpengaruh oleh ruang dan waktu, sementara ushlub dapat berubah seiring dengan kemajuan zaman dan tempat.

Dakwah adalah menyampaikan kebenaran kepada manusia agar mengikuti jalan kebenaran. Oleh karena itu, dakwah harus dijalankan dengan metode dan cara-cara yang benar pula. Ada beberapa metode dakwah, antara lain : Pertama, dakwah Fardiah merupakan metode dakwah yang dilakukan seseorang kepada orang lain (satu orang) atau kepada beberapa orang dalam jumlah yang kecil dan terbatas. dakwah Fardiah ini melibatkan aspek psikologis yang besar antara da'i dan madh'u. Kedua, dakwah Ammah yang dilakukan oleh seseorang dengan media lisan yang ditujukan kepada orang banyak dengan maksud menanamkan pengaruh kepada mereka. Para da'i biasanya menyampaikan khotbah (pidato), seminar atau dalam bentuk training keislaman. Ketiga, dakwah bil-Lisan, yakni penyampaian informasi atau pesan dakwah melalui lisan (ceramah atau komunikasi langsung antara subyek dan obyek dakwah). Metode ini bisa diterapkan dalam pertemuan-pertemuan yang melibatkan banyak orang seperti pertemuan keluarga, reuni alumni, seminar, atau pengajian. Keempat, dakwah bil-Haal, dengan mengedepankan perbuatan nyata. Misalnya dengan berbuat baik kepada objek dakwah dengan cara memberikan teladan kebaikan atau ikut serta memberikan solusi-solusi praktis dalam kehidupan mad'u. Yang kelima, dakwah bit-Tadwin, atau pola dakwah melalui tulisan, baik dengan menerbitkan kitab-kitab, buku, majalah, internet, koran, dan tulisan-tulisan yang mengandung pesan dakwah. Keenam adalah dakwah bil Hikmah, yang berdakwah dengan cara arif bijaksana, semisal melakukan pendekatan sedemikian rupa sehingga pihak obyek dakwah mampu melaksanakan dakwah atas kemauannya sendiri, tidak merasa ada paksaan, tekanan maupun konflik.

Metode dakwah merupakan salah satu unsur penting dalam dakwah selain da'i, mad'u, dan sarana dakwah. Kesuksesan dakwah diantaranya sangat ditentukan oleh bagaimana dakwah itu dilaksanakan. Tata cara atau metode dalam berdakwah termasuk pengemasan materi, sikap dan cara penyampaian materi dakwah menjadi lebih penting dari materi dakwahnya. Artinya, betapa pun sempurna dan matangnya materi dakwah, lengkapnya analisis dan aktualnya isu-isu yang dibahas, bila 
tidak disampaikan secara sistematis, akan menimbulkan kesan yang kurang baik. Sebaliknya, walaupun materi dakwahnya kurang sempurna, bahan sederhana dan isu-isu yang disampaikan kurang aktual, namun disajikan dengan cara yang menarik dan menggugah maka akan menimbulkan kesan yang menggembirakan (Aliyudin, 2010). Ushlub dakwah harus mampu menjawab tantangan zaman. Karena itu harus diupayakan semaksimal mungkin agar saranasarana teknologi yang berkembang pesat saat ini dapat dimanfaatkan untuk menunjang aktifitas dakwah. Seperti televise, radio, internet, media social dan berbagai media yang lain. Untuk itu, da'i di era ini tidak saja dituntut untuk menguasai materi dakwah semata namun memiliki keahlian dalam memanfaatkan sarana-sarana yang ada dalam menunjang efektifitas dan efisiensi dakwah.

Namun demikian, kondisi ini tidak serta merta menghilangkan metode atau ushlub dakwah klasik yang dianggap masih relevan. Menurut Jamaluddin Kafie metode klasik yang masih tetap kekinian dan dapat di teruskan adalah: 1) Metode sembunyi-sembunyi, pendekatan kepada sanak keluarga terdekat. 2) Metode bil lisan, bil qalam, dan bil hal. 3) Metode bil hikmah, mauidah hasanah, mujadalah bi alati hiya ahsan. 4) Metode tabsyir wa altandzir, amar ma'ruf nahi munkar, ta'awun ala al-biri wa al-taqwa, wala ta'awanu ala al-ismi wa al-udwan, dalla ala alkhair, tawashau bi al-haq wa al-sabr, tadzkirah (Kafie, 1993).

\section{KEDUDUKAN PENGUASA (PEMIMPIN) DALAM ISLAM}

Dalam parameter Islam, setiap orang pada hakikatnya adalah pemimpin. Besar kecilnya kepemimpinan tergantung pada apa dan siapa yang ia pimpin. Ayah adalah pemimpin dalam keluarga. Gubernur pemimpin diprovinsi. Pemuda pemimpin bagi dirinya sendiri dan seterusnya.

Secara etimologi, pemimpin dalam Kamus Besar Bahasa Indonesia berasal dari kata dasar "pimpin" yang jika mendapat awalan "me" menjadi "memimpin" yang berarti menuntun, menunjukkan jalan dan membimbing. Perkataan lain yang sama pengertiannya adalah mengetuai, mengepalai, memandu dan melatih dalam arti mendidik dan mengajari supaya dapat mengerjakan sendiri. Adapun pemimpin berarti orang yang memimpin atau mengetuai atau mengepalai. Sedang kepemimpinan menunjukkan pada semua perihal dalam memimpin, termasuk kegiatannya (Tim, 1999).

$$
\text { Bila kita mendengar }
$$

perkataan kepemimpinan dalam Islam biasanya asosiasi pertama terarah pada "kepemimpinan tertinggi bagi umat Islam" yang terkenal dengan sebutan khalifah, imamah, imaratul mukminin dan sebagainya. Artinya, kepemimpinan tertinggi bagi umat Islam dalam urusan agama dan dunia. Definisi yang populer mengenai khalifah adalah pemimpin tertinggi dalam urusan agama dan dunia menggantikan Rasululloh Saw (Sidiq, 2014)
Dalam artikel ini tidak dibahas tentang sistem pemerintahan dalam Islam (khilafah) dan perbedaannya dengan republic, kerajaan atau kekaisaran. Karena pembahasan tersebut memerlukan 
tempat tersendiri dalam kajian-kajian yang lain.

Dalam syari'at Islam, pemimpin atau penguasa mempunyai kedudukan yang tinggi dan mulia. Hal ini sesuai dengan tingginya tugas dan besaranya tanggung jawab serta beratnya beban yang mereka pikul, menjaga agama dan mengatur dunia sebagai pengganti tugas kenabian (Bay, 2011). Walaupun fungsi kepemimpinan dalam Islam ini mulai ditinggalkan karena negeri ini tidak menganut system Islam, kajian tentang cara atau metode dakwah kepada pemimpin terhadap relevan untuk dilakukan.

\section{Ketinggian kedudukan} pemimpin dalam Islam tidak serta merta membolehkan masyarakat untuk mengkultuskannya. Pemimpin tetaplah manusia yang bisa benar dan salah. Maka tidak ada ketaatan mutlak kepada penguasa. Disinilah terdapat ruang bagi para da'i dalam memainkan peranannya sebagai juru dakwah atau juru kritik apabila dijumpai adanya penyimpangan yang dilakukan penguasa dalam menjalankan roda kekuasaannya.

\section{Hak Penguasa Atas Rakyat}

Penguasa memiliki hak dari masyarakat yang harus ditunaikan. Hak ini menjadi rambu-rambu bagi masyarakat, ulama atau da'i dalam menjalankan kewajibannya kepada pemimpin yaitu memberi nasehat atau kritik yang konstruktif. Diantara hak-hak pemimpin dan kewajiban terhadap mereka adalah sebagai berikut:
a. Ikhlas Dan Mendoakan
Pemimpin
Pemimpin memiliki tugas yang berat dalam mengurusi urusan rakyat. Karena itu sudah menjadi kewajiban bagi rakyat untuk mencintainya dengan mendoakan kebaikan atasnya. Bentuk kecintaan itu dapat diimplementasikan dalam bentuk nasehat yang baik, sebagaimana di sebut dalam hadis Tamin bin Aus al Daari, ia berkata : “ Rasulullah SAW bersabda: "Agama itu adalah nasehat, kami berkata : "bagi siapa? Beliau bersabda : Bagi Allah, Kitab-Nya, Rasul-Nya, pemimpin kaum muslimin dan umat mereka".

Berkaitan dengan hadis ini, Dr.Musthofa Dieb Al Bugho memberikan penjelasan bahwa nasehat kepada Allah artinya beriman kepada Allah dan tidak tersesat dalam mensifati dan meyakini sifat Allah. Nasehat kepada kitabullah artinya dengan beriman kepada kitab-kitab samawi yang diturunkan dari sisi Allah. Nasehat kepada Rasulullah artinya dengan membenarkan risalahnya, mengimani apa yang dibawanya berupa al-Qur'an dan Sunnah. Sementara nasehat kepada para pemimpin kaum muslimin artinya membantu mereka dalam mewujudkan kebenaran, menaati dan mengingatkan mereka, mengkritik mereka dengan kasih sayang,hikmah dan lemah lembut (Bugho, 2000).

b. Menghormati Dan Memuliakan Pemimpin

Pemimpin muslim yang berpegang kepada kebenaran ,tidak melakukan kedzaliman, menegakan hukum-hukum Allah dan mencintai rakyatnya wajib untuk dihormati dan dimuliakan. Hal ini sebagaimana sabda Rasulullah SAW : "Dari Abi Bakrah, ia berkata : aku mendengar Rasulullah SAW bersabda. "Barangsiapa yang memuliakan penguasa Allah di dunia, niscaya Allah akan memuliakannya pada hari 
kiamat. Barangsiapa yang menghinakan pengauasa Allah di dunia, niscaya Allah akan menghinakannya pada hari kiamat".

Sebaliknya apabila penguasa melakukan penyimpangan dari kebenaran maka menjadi kewajiban masyarakat yang mengetahuinya untuk melakukan kritik yang konstruktif, baik secara sembunyi atau terang-terangan. Hal ini berdasarkan sabda nabi SAW; "Seutama-utama jihad adalah menyampaikan kalimat yang haq kepada penguasa (sulthan) atau pemimpin (amiir) yang zalim." (HR Abu Dawud, Tirmidzi, dan ibnu majah).

Kebolehan mengkritik penguasa secara terbuka juga diperkuat oleh praktik para shahabat yang sering mengkritik para khalifah secara terbuka. Diriwayatkan dari Nafi' Maula Ibnu Umar RA, ketika menaklukkan Syam, Khalifah Umar bin Khaththab tidak membagikan tanah Syam kepada para mujahidin. Maka Bilal RA memprotes dengan berkata, "Bagilah tanah itu atau kami ambil tanah itu dengan pedang!". Hadits ini menunjukkan Bilal mengkritik Khalifah Umar secara terbuka di hadapan umum.

c. Taat Dalam Perkara Selain Maksiat

Di wajibkan adanya pemimpin tentu dimaksudkan untuk menjaga dan mencari kemaslahatan manusia dalam kehidupan bermasyarakat. Untuk itu diperlukan adanya pemimpin yang ditaati. Pertanyaannya adalah apakah ketaatan kepada pemimpin atau penguasa itu bersifat mutlak/absolut atau kondisional. Dalam konteks ini, madzab syi'ah berpandangan bahwa pemimpin itu bersifat ma'shum sehingga ia mutlak untuk ditaati.
Sementara dalam madzab sunni, pemimpin tetaplah manusia yang memiliki potensi kebenaran dan kesalahan.

Menurut Abudin Nata, yang dikutip oleh Kaizal Bey, ketaatan kepada ulil amri atau pemimpin sifatnya kondisional (tidak mutlak), karena betapapun hebatnya ulil amri itu, namun ia tetap manusia yang memiliki kekurangan dan tidak dapat dikultuskan. Atas dasar inilah, mentaati ulil amri bersifat kondisional. Jika produk dari ulul amri tersebut sesuai dengan ketentuan Allah dan Rasul-Nya maka wajib di ikuti ; sedangkan jika produk ulil amri tersebut bertentangan dengan kehendak Tuhan maka tidak wajib mentaatinya (Nata, 2004).

Ada beberapa riwayat dalam hadits Rasulullah terkait dengan kondisionalnya ketaatan masyarakat kepada penguasa atau ulil amri. Diriwayatkan dari Ibnu Umar bahwa Nabi SAW bersabda, "Seorang Muslim wajib mendengardan taat terhadap perintah yang disukainya maupun tidak. Kecuali ia diperintah engerjakan kemaksiatan, maka ia tidak wajib mendengar dan taat.". (HR Bukhari dan Muslim) (Nawawi, 1999)

\section{Kewajiban Penguasan}

Selain hak-hak pemimpin diatas yang harus dipenuhi oleh rakyat, penguasa juga memiliki kewajiban yang mesti ditunaikan atas rakyatnya. Apabila kewajiban ini dilalaikan akan berakibat pada nasibnya didunia dan diakherat. Oleh karena beratnya tanggung jawab kepemimpinan ini, Islam melarang umat Islam meminta atau mengajukan diri sebagai penguasa atau pejabat pemerintahan. Diriwayatkan dalam sebuah hadits 
dari Abu Musa bahwa ia berkata, "aku dan dua orang dari kabilah pamanku menghadap Rasulullah saw. Salah seorang dari keduanya berkata."Wahai Rasulullah, angkatlah aku untuk memangku salah satu jabatan yang telah dikaruniakan Allah ta'ala kepadamu. Orang yang satunya laagi juga mengutarakan hal yang serupa. Nabi SAW bersabda, "Sungguh, demi Allah, aku tidak akan memberikan jabatan tersebut kepada orangorang yang memintanya atau orangorang yang memintanya. (HR. Muslim, hadits No. 3402).

Atas dasar hadits diatas, berambisi meraih jabatan dalam pemerintahan sesungguhnya bukan merupakan karakteristik pemimpin yang baik. oleh karena itu, orang yang berambisi meraih jabatan tidak sepantasnya mendapatkan kedudukan tersebut (Fathullah, 2010).

Beberapa kewajiban penguasa yang terpenting adalah sebagai berikut :

a. Memelihara kemaslahatan masyarakat.

Dalam perspektif Islam, seorang penguasa memiliki kewajiban yang sangat berat yaitu menghadirkan dan memelihara kemaslahatan umat dan mencegah setiap sesuatu yang dapat membahayakan atau mengganggu kemaslahatan masyarakat. Kemaslahatan itu mencakup terpenuhinya kebutuhan pokok masyarakat seperti kebebasan menjalankan agamanya, ketersediaan sandang, pangan dan papan, rasa aman, pendidikan dan sebagainya.

Penguasa wajib memastikan anggota masyarakatnya memiliki akses terhadap berbagai macam kebutuhannya. Disinilah kemudian dibutuhkan perangkat aturan atau system yang baik guna menopang atau memudahkan tugas penguasa dalam memenuhi tanggung jawabnya itu.

Dalam sejarah Islam, dijumpai banyak jejak kebajikan yang difungsikan untuk melayani kesejahteraan masyarakat. Syekh Yusuf Qaradhowi, dalam bukunya yang berjudul, Distorsi Sejarah Islam, menulis bahwa salah satu implementsi humanism tinggi dalam sejarah Islam adalah berbuat baik terhadap manusia dan membentu mereka dalam keadaan susah atau menderita. Beberapabentuk implementasinya secara rinci adalah dibentuknya wakaf bejana pecah, wakaf anjing tersesat, wakaf peminjaman perhiasan perkawinan, wakaf untuk para istri yang marah, wakaf penghibur orang sakit dan orang asing,wakaf penghibur pasien dan berbagai lembaga kemanusiaan yang lain.

b. Melakukan Amar Ma'ruf Nahi Munkar

Menurut Ahmad Mahmud, penguasa juga bertanggung jawab untuk mencegah berbagai kemunkaran; apakah kemunkaran itu dilakukan oleh individu atau jamaah. Dalam hal ini, penguasa memiliki kewenangan untuk memaksa manusia, baik individu atau jamaah, agar menunaikan segala kewajiban yang dibebankan oleh syariat kepada mereka (Mahmud, 2009).

Adapun yang dimaksud amar ialah suatu tuntutan suatu perbuatan dan pihak yang lebih tinggi kedudukannya kepada pihak yang lebih rendah kedudukannya (Umam, 1998). Sementara ma'ruf menurut arti lughah/ bahasa ialah suatu kata 
yang diketahui oleh hati dan menenangkannya, menurut istilah semua isim yang dicintai oleh Allah (Al-Audah, 1996).

Adapun Nahi menurut bahasa meiliki arti larangan. Sementara menirut istilah ialah suatu lafad yang digunakan untuk meninggalkan suatu perbuatan. Sedangkan menurut ulama ushul fiqih Islam ialah "Lafad yang menyuruh kita untuk meninggalkan suatu pekeerjaan yang diperintahkan oleh orang yang lebih tinggi dan kita (Umam, 1998).

Posisi penguasa dalam struktur masyarakat memiliki kedudukan dan kekuatan sehingga ia bisa menjaga agama, kehormatan dan harta manusia dari gangguan dan kedzaliman orang kafir bahkan saudara sesama muslim berbuat munkar. Karena itu penguasa dapat mencegahnya. Imam muslim meriwayatkan, sanadnya dari Abu Zaid ra, ia berkata lalu bersabda, yang artinya :

“Dari Abu Sa'id Al Khudri r.a berkata : Saya mendengar Rasulullah SAW bersabda : Siapa yang melihat kemunkaran maka rubahlah dengan tangannya, jika tidak mampu maka rubahlah dengan lisannya, jika tidak mampu maka (tolaklah) dengan hatinya dan hal tersebut adalah selemah-lemahnya iman". (HR Muslim).

Adapun dampak yang bakal ditimbulkan ketika seorang pemimpin tidak melakukan amar ma'ruf nahi munkar adalah para pelaku maksiat dan orang yang durhaka akan berani serta bersemangat untuk menyebarkan kejahatan dan kerusakan tanpa memperdulikan hal-hal yang disucikan dan menyucikan syariat (Bugho, 2000). Misalnya, penistaan agama, propaganda LGBT, kebebasan dan lain-lain. Bila kondisi ini terus dibiarkan maka akan menimbulkan adzab Allah SWT.

c. Menjalankan Hukum Islam Kewajiban menerapkan hukum-hukum Islam seperti hudhud, qishos (Maraknya kasus kriminalitas yang terjadi di Indonesia saat ini telah membuat keresahan di kalangan masyarakat. Peraturan hukum di Indonesia belum mampu membuat para pelaku jera, sehingga kasus pembunuhan terus saja terjadi dalam dekade ini. Walaupun para pelaku telah diadili melalui peradilan hukum Indonesia, hukuman yang diterima mereka belum setimpal dengan apa yang telah mereka perbuat. Untuk itu diperlukan suatu hukum yang dapat mengadili para pelaku seadil-adilnya yaitu hukum Qishash) (Anisah, 2016), jinayat, uqubat dan sebagainya melalui institusi Islam merupakan kewajiban terpenting bagi seorang pemegang kekuasaan. Sebab sebagian dari hukum-hukum Islam memerlukan adanya Negara dalam pelaksanaannya.

Dalam buku 'Anda Bertanya,IslamMenjawab', Mutawalli as Sya'rawi, menyatakan bahwa wakil rakyat dapat dimintai pertanggung jawabannya apabila sampai menyetujui undang-undang yang tidak cocok atau bersifat sekuler misalnya. Hendaknya para wakil pertama-tama harus bertanggung jawab kepada Allah dan agar hukum Allah dapat dijadikan pelindung dari tiapundangundang yang diterapkan (Sya'rowi, 2007).

\section{METODE DAKWAH KEPADA PENGUASA}


Dakwah Islam adalah menyerukan kebaikan yang harus dilakukan dengan cara-cara yang baik. Ukuran kebaikan dalam dakwah tentu saja harus didasarkan pada bagaimana nabi Muhamad SAW menjalankan aktifitas dakwahnya. Dakwah dan Islam merupakan dua hal yang tidak dapat dipisahkan satu sama lain, karena Islam tidak akan tumbuh dan berkembang tanpa dakwah (Ihsan, 2008).

Dakwah merupakan aktivitas yang menuntut pembaharuan secara terus-menerus baik dari sisi content, cara, strategi, dan atau metodenya maupun kualifikasi pelakunya. Hal ini karena adanya dinamika sasaran dakwah dan lingkungan sosial yang terus berubah yang menuntut selalu adanya pembaharuan. Pembaharuan ini dalam rangka mencari format yang relevan dan kontekstual dalam dakwah. (Ghofur, 2014).

Salah satu elemen objek dakwah yang harus mendapatkan perhatian adalah penguasa atau pemimpin. Dapat dikatakan bahwa pemimpin merupakan objek dakwah yang paling penting sebab keshalehan atau kebaikan seorang pemimpin akan berpengaruh pada kebaikan masyarakat yang dipimpinnya.

Pemimpin baik akanmelahirkan kebijakan-kebijakan baik yang menguntungkan masyarakat dan dakwah Islam. Sementara pemimpin yang buruk akan menghambat masyarakat menjadi baik. Disinilah kemudian dakwah kepada penguasa menjadi penting. Walaupun demikian, dakwah kepada penguasa bukan hal yang mudah. Dalam menjalankan tugas dakwahnya kepada penguasa, sangat mungkin seorang da'i akan menghadapi persekusi apabila dakwah yang disampaikannya mengusik kepentingan kekuasaannya.

Sebagaimana dakwah kepada manusia secara umum, ada beberapa metode dakwah yang ditujukan secara khusus kepada penguasa, yaitu :

\section{Dakwah Melalui Surat/Tulisan}

Surat merupakan sarana komunikasi klasik jarak jauh yang tetap relevan hingga era modern saat ini walaupun peranannya mulai tergeser oleh media elektronik seperti email, whatApp, facebook, twitter, yahoo dan sebagainya. Demikian besarnya perkembangan media elektronik tidak serta merta menghilangkan relevansi surat sebagai komunikasi resmi khususnya dalam level lembaga baik swasta maupun pemerintahan.

Dengan kata lain, dakwah melalui tulisan bukanlah cara yang baru dalam tradisi dakwah Islam, justru yang menjadi agent of change adalah Nabi Muhammad SAW yang pertama mengenalkan metode dakwah melalui tulisan yang ditujukan kepada para penguasa non-muslim saat itu. Secara tidak langsung Rasulullah SAW telah mencontohkan kepada umatnya tentang dakwah beliau dalam mempengaruhi orang yang kafir agar menjadi muslim dan orang yang buruk tingkah lakunya menjadi baik. Salah satu cara dakwah beliau adalah dakwah dengan menggunakan media surat kepada para raja yang disampaikan oleh duta-duta Rasulullah SAW (Illahi, (2007).

\begin{tabular}{llr}
\multicolumn{3}{c}{ Surat pertama yang berisikan } \\
dakwah & Rasulullah kepada \\
penguasa & adalah surat yang
\end{tabular}


disampaikan pada raja atau Kaisar Najasyi pada tahun ke-5 Hijriah atau 628 M. Adapun isi surat seruan Rasulullah kepada Kaisar Najasyi itu adalah sebagai berikut :

"Salam bagimu, sesungguhnya aku bersyukur kepada Allah yang tidak ada Tuhan kecuali Dia, Raja Yang Maha Suci, Yang Maha Sejahtera, Yang Menganugrahi Keamanan, Yang Maha Memelihara, dan aku bersaksi bahwa Isa putra Maryam adalah ruh dari Allah yang diciptakan dengan kalimat-Nya, yang disampaikan-Nya kepada Maryam yang terpilih, baik dan terpelihara. Maka ia hamil kemudian diciptakan Isa dengan tiupan ruh dari-Nya, sebagaimana diciptakan Adam dari tanah dengan tangan-Nya. Sesungguhnya, aku mengajakmu ke jalan Allah. Dan aku telah sampaikan dan menasehatimu, maka terimalah nasehatku. Dan, salam bagi yang mengikuti petunjuk".

Di riwayatkan bahwa ketika nabi Muhammad SAW menulis surat kepada Najasyi (Raja Negus) dan menyerunya kepada Islam, Raja Najasyi mengambil surat itu, lalu meletakkannya kewajahnya dan turun dari singgasana. la pun masuk Islam (Dalinur, 2017).

Dakwah melalui media surat yang terjadi antara nabi dengan raja najasyi, Heraclius dan sebagainya adalah dakwah yang terjadi antar kerajaan atau dua kepala Negara. Sebab peristiwa itu terjadi ketika nabi telah hijrah ke Madinah dimana posisi nabi Muhamad telah berubah dari sebelumnya sebagai ketua gerakan dakwah menjadi kepala Negara. Pertanyaannya adalah mungkinkah dakwah model ini dilakukan oleh da'i/ulama biasa kepada kepala Negara? Menurut kami, hal itu sangat mungkin dilakukan. Apalagi perkembangan fungsi surat dari zaman ke zaman mengalami perubahan fungsi yang cukup berarti. Hanya saja, konten dan model penulisan surat itu harus disesuaikan dengan kaedah dan norma-norma penulisan surat yang benar.

Menurut Prof. Mustofa Ya'kub, keseluruhan surat Rasulullah dapat diklasifikasikan sebagai berikut :

a. Surat yang berisi seruan untuk masuk agama Islam. Surat jenis seperti ini ditujukan kepada orang non-Muslim (ahli kitab atau kaum musyrikin) yang pada saat itu berkedudukan sebagai penguasa (kaisar, atau kedudukan lainnya yang setara), walinegara (jabatan setingkat gubernur), pemimpin suku (kabilah), juga kepada perseorangan.

b. Surat yang berisi tentang aturan agama Islam, seperti surat yang di dalamnya memuat mengenai penjelasan zakat, shadaqah dan sebagainya. Surat dalam kelompok ini biasanya disampaikan kepada mereka yang sudah menjadi muslim tapi masih membutuhkan beberapa penjelasan dari Rasulullah.

c. Surat yang berisi tentang hal-hal yang wajib dikerjakan orangorang non-muslim yang tinggal dan hidup di wilayah dan pemerintahan Islam (Madinah). Surat dengan jenis seperti ini disampaikan kepada golongan non-muslim yang telah membuat perjanjian damai dengan Rasulullah (Ya'cub, 1997)

2. Mengkritik Penguasa Secara Terbuka 
Sebagian kaum muslimin memahami bahwa mengkritik penguasa secara terang-terangan adalah tindakan yang diharamkan. Mereka mendasarkan pendapatnya pada hadits Rasulullah bahwa Dari Ibnu Hakam meriwayatkan, bahwa Nabi bersabda, "Barangsiapa yang ingin menasihati pemimpin, maka jangan melakukannya secara terang-terangan. Akan tetapi, nasihatilah dia di tempat yang sepi. Jika menerima nasihat, itu sangat baik. Dan bila tidak menerimanya, maka kamu telah menyampaikan kewajiban nasihat kepadanya." [HR Imam Ahmad].

Menurut Abu Ahmad Zainal

Abidin, Sangat tidak bijaksana mengoreksi dan mengkritik kekeliruan para pemimpin melalui mimbar-mimbar terbuka, tempattempat umum ataupun media massa, baik elektronik maupun cetak. Yang demikian itu menimbulkan banyak fitnah. Bahkan terkadang disertai dengan hujatan dan cacian kepada orang per orang. Seharusnya, menasihati para pemimpin dengan cara lemah lembut dan di tempat rahasia, sebagaimana yang dilakukan oleh Usamah bin Zaid tatkala menasihati Utsman bin Affan, bukan dengan cara mencaci-maki mereka di tempat umum atau mimbar.

Padahal, menyampaikan nasehat sebagai upaya mengubah perilaku munkar atau zalim orang lain -baik penguasa maupun rakyat jelata- sesungguhnya tidak dapat dilepaskan dari konteks dakwah bi al-lisan (melalui lisan maupun tulisan), sebagaimana sabda Nabi :

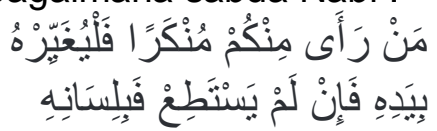

"Siapa saja yang menyaksikan kemunkaran, hendaknya mengubahnya dengan tangannya. Jika tidak mampu, maka hendaknya dengan lisannya." (H.r. Muslim).

Bagaimana cara merubah kemunkaran sangat bergantung bagaimana pelakunya melakukan kemunkaran tersebut. Setidaknya ada dua cara manusia dalam melakukan kemunkaran, yaitu :

Pertama, kemunkaran yang dilakukan secara diam-diam, rahasia dan pelakunya berusaha merahasiakannya;

Kedua, kemunkaran yang dilakukan secara terbuka, demonstratif dan pelakunya tidak berusaha untuk merahasiakannya, justru sebaliknya.

Jenis kemunkaran yang pertama, dan bagaimana cara mengubah kemunkaran tersebut dari pelakunya, tentu berbeda dengan kemunkaran yang kedua. Orang yang tahu perkara tersebut hendaknya menasehatinya secara diam-diam, dan kemunkaran yang dilakukannya pun tidak boleh dibongkar di depan umum. Sebaliknya, justru wajib ditutupi oleh orang yang mengetahuinya (Abdurrahman, 2017). Sebagaimana sabda Rasulullah: "Siapa saja yang menutupi satu aib, maka (pahalanya) seolah-olah sama dengan menghidupkan bayi perempuan yang dikubur hiduphidup dari kuburnya." (H.r. Ibn Hibban)

Ada pun jenis kemunkaran yang kedua, yaitu kemunkaran yang dilakukan secara terbuka, dan terang-terangan. Dalam kasus seperti ini, menurut Hafidz Abdurahman, pelaku kemunkaran tersebut sama saja dengan menelanjangi dirinya sendiri dengan 
kemunkaran yang dilakukannya. Untuk menyikapi jenis kemunkaran yang kedua ini, sikap orang Muslim terhadapnya dapat dipilah menjadi dua:

a. Jika kemaksiatan atau kemunkaran tersebut pengaruhnya terbatas pada individu pelakunya, dan tidak mempengaruhi publik, maka kemaksiatan atau kemunkaran seperti ini tidak boleh dibahas atau dijadikan perbincangan. Tujuannya agar kemunkaran tersebut tidak merusak pikiran dan perasaan kaum Muslim, dan untuk menjaga lisan mereka dari perkara yang sia-sia. Kecuali, jika kemaksiatan atau kemunkaran tersebut diungkapkan untuk mengingatkan masyarakat akan bahaya orang fasik yang melakukan kemaksiatan tersebut. Maka, pengungkapan seperti ini boleh.

b. Jika kemaksiatan atau kemunkaran tersebut pengaruhnya tidak terbatas pada individu pelakunya, sebaliknya telah mempengaruhi publik, misalnya seperti kemunkaran yang dilakukan oleh sebuah institusi, baik negara, organisasi, kelompok atau komunitas tertentu, maka kemaksiatan atau kemunkaran seperti ini justru wajib dibongkar dan diungkapkan kepada publik agar mereka mengetahui bahayanya untuk dijauhi dan ditinggalkan supaya mereka terhindar dari bahaya tersebut. Inilah yang biasanya disebut kasyf al-khuthath wa almu'amarah (membongkar rancangan dan konspirasi jahat) atau kasyf al-munkarat

(membongkar kemunka-ran).

Ini didasarkan pada sebuah hadits Zaid bin al-Arqam yang mengatakan, "Ketika aku dalam suatu peperangan, aku mendengar Abdullah bin 'Ubay bin Salul berkata: 'Janganlah kalian membelanjakan (harta kalian) kepada orang-orang yang berada di sekitar Rasulullah, agar mereka meninggal-kannya. Kalau kita nanti sudah kembali ke Madinah, pasti orang yang lebih mulia di antara kita akan mengusir yang lebih hina. Aku pun menceritakannya kepada pamanku atau 'Umar, lalu beliau menceritakan-nya kepada Nabi saw. Beliau saw. pun memanggilku, dan aku pun menceritakannya kepada beliau."

Salah satu bentuk atau cara mengkritik penguasa adalah melalui aksi demonstrasi. Demonstrasi merupakan salah satu sarana atau alat sangat terkait dengan tujuan digunakannya sarana atau alat tersebut dan cara penggunaannya. Sebagaimana misalnya pisau, dapat digunakan untuk berjihad, tetapi dapat juga digunakan sebagai alat merampok. Sehingga niat sangat menentukan hukum demonstrasi. Rasulullah saw. bersabda:

Sesungguhnya amal-amal itu terkait dengan niat, dan sesungguhnya setiap orang akan memperoleh sesuai dengan niatnya. Maka barangsiapa hijrahnya karena Allah dan Rasul-Nya, maka hijrahnya itu mendapatkan keridhoan Allah dan Rasul-Nya. Barangsiapa yang hijrahnya karena dunia, maka akan mendapatkannya, atau karena wanita maka ia akan menikahinnya. Maka hijrah itu sesuai dengan niatnya (Muttafaqun alaihi). 
Dengan demikian, apabila aksi demontrasi dilakukan sebagai upaya untuk melakukan amar ma'ruf nahi munkar baik kepada penguasa maupun pihak-pihak yang secara jelas mempropagandakan kedzaliman maka demonstrasi dapat dijadikan wasilah untuk menyampaikan kebenaran.

\section{Mengingkari kedzaliman penguasa}

Sebagai manusia, penguasa pun memiliki kecendrungan menyimpang dari norma dan garisgaris hukum yang telah ditetapkan syara'. Apalagi bila penguasa tersebut dari awal memang didesain bukan untuk menerapkan hukum Islam melainkan menjalankan aturan yang dibuat oleh manusia berdasarkan asumsi dan studi banding. Potensi untuk menyimpang tentu lebih besar.

Oleh karena itu, Islam menetapkan bahwa terhadap pemimpin yang menyimpang itu untuk mengingkarinya baik dengan lisan, tulisan atau hati. Sebagaimana sabda Rasulullah bahwa "Akan ada para pemimpin, lalu kalian mengetahui (kemkrufannya) dan mengingkari (kemunkrannya). Siapa yang mengetahui (kemkrufannya),dia bebas. Dan siapa yang mengingkari (kemunkrannya), dia selamat. Akan tetapi, orang yang ridha dan mengikuti (celaka)". Mereka berkata,'tidakah kita perangi saja mereka? Beliau bersabda "tidak, selama mereka sholat" (HR Muslim)

$$
\text { Hadits ini menjelaskan }
$$

keharusan mengingkari kemunkaran penguasa dan para pemimpin. Siapasaja yang mngingkari kemunkaran itu sesuai kemmpuannya, baik dengan tangan atau lisannya, ia selamat dari sifat mencari muka dan nifak serta bebas dari berserikat dalam dosanya. Jika tidak mampu mengingkari kemunkaran maka ia hrus membenci kemunkaran itu dengan hati sehingga ia pun akan terbebas dari berserikat dalam dosanya (Abdurrahman, 2017).

\section{KESIMPULAN}

Dakwah sering direduksi tujuannya hanya kepada perbaikan akhlak individu. Padahal Islam bukan hanya bicara akhlak individu tetapi persoalan keluarga, masyarakat hingga Negara, termasuk didalamnya penguasa. Dengan kata lain dakwah harus diarahkan kepada seluruh lapisan masyarakat sesuai dengan karakter Islam yang luas.

$$
\text { Penguasa merupakan }
$$

lapisan masyarakat yang tertinggi dalam struktur masyarakat di tengah kehidupan manusia. Keputusannya sangat menentukan nasib masyarakat yang dipimpinnya. Bila keputusannya baik dan adil maka akan berdampak positif bagi kehidupan masyarakat. Sebaliknya bila keputusannya dzalim maka akan menyengsarakan masyarakat. Padahal kekuasaan dimana-mana memiliki kecendrungan yang besar untuk menyimpang.

Disinilah kemudian dakwah kepada penguasa menjadi penting. Namun harus tetap dibarengi dengan cara atau metode yang benar sesuai dengan kedudukan penguasa yang tinggi itu. Diantara metode dakwah yang bisa dilakukan adalah dengan menyampaikan dakwah melalui surat,mengkritik secra terbuka atau minimal menginkari kedzaliman penguasa apabila ia berbuat dzalim. 
DAFTAR PUSTAKA

Abdurahman, Yahya. 2017. Wajib Mengingkari Penguasa, Jurnal Al Waie, No. 199 Vol. XVII, 531

Abdurrahman, Hafidz. 2017. Bolehkah Menasehati Penguasa di Tempat Umum? Jurnal Al Waie, No. 199. Vol. XVII, 5-31

Al-Audah, Salam bin Fahd. 1996. Urgensi Amar Ma"ruf Nahi Mungkar, Solo: CV. Pustaka Setia

Aliyudin. 2010. Prinsip-prinsip Metode Dakwah Menurut AlQur'an. Jurnal IImu Dakwah Vol. 4 No. 15

Amin, Samsul Munir. 2009. IImu Dakwah, Jakarta: Amzah.

Anisah, Siti. 2016. Penerapan Hukum Qishash Untuk Menegakkan Keadilan, Jurnal Syariah, hlm. 98

Aziz, Moh. Ali. 2004. Ilmu Dakwah, Jakarta, Kencana.

Bay, Kaizal. 2011. Pengertian Ulil Amri dalam Al-Qur'an dan Implementasinya dalam Masyarakat Muslim, Jurnal Ushuluddin Vol. XVII No. 1.

Bugho, Musthofa Dieb, dkk, 2000. al-Wafi: Syarah hadits arbain Imam Nawawi, pent. Iman Sulaiman, Lc, Jakarta: Pustaka Al Kautsar

Dalinur, dkk,. 2017. Metode Dakwah Rasulullah SAW kepada Golongan Non Muslim di Madinah, Wardah, Vol.18, No.1, hlm. 91

Fathullah, Abu Lukman. 2010. 60 Hadits Sulthaniyah, Bogor: Pustaka Thoriqul Izzah.

Ghafur, Waryono Abdul. 2014. Dakwah Bil-Hikmah Di Era Informasi Dan Globalisasi Berdakwah Di Masyarakat
Baru, Jurnal IImu Dakwah, Vol. 34, No.2.

Ghazali, Imam. 1997. Di Balik Ketajaman Mata Hati, Pent. Mahfudli Sahli, Jakarta: Pustaka Amani, Cet. 1

Ihsan, Muhammad Alim. 2008. Dakwah: Suatu Pendekatan Kultural, Jurnal Hunafa Vol. 5 No. 1.

Ilaihi, Wahyu,. Harjani Hefni,. 2007. Pengantar Sejarah Dakwah, Jakarta: Kencana

Kafie, Jamaluddin . 1993. Psikologi dakwah, Surabaya: Indah Surabaya.

Mahmud, Ahmad. 2002. Dakwah Islam, Bogor, Pustaka Thoriqul Izzah.

Mahmud, Ahmad. 2009. Dakwah Islam, Bogor,Pustaka Thoriqul Izzah.

Maqfiroh. 2014. Mujadalah menurut Al-Qur'an (Kajian Metodologi Dakwah), Jurnal Al-Bayan / Vol. 20, No. 29.

Munawir, Ahmad Warson AlMunawir. 1984. Kamus ArabIndonesia, Yogyakarta: Ponpes Al-Munawir.

Nata, Abuddin. 2004. Metodologi Studi Islam, PT. Raja Garfindo, Persada, Jakarta.

Nawawi, Imam. 1999. Riyadus Sholihin, Pent. Achmad Sunarto, Jakarta: Pustaka Amani, Cet. IV.

Sidiq, Umar. 2014. Kepemimpinan Dalam Islam: Kajian Tematik Dalam Al-Quran Dan Hadits, Dialogia, Vol. 12 No. 1.

Suparta, Munzier. 2009. Metode Dakwah, Jakarta: Rahmat Semesta.

Sya'rowi, Mutawalias 2007. Anda bertanya Islam Menjawab, Jakarta: Gema Insani Press. 
Al-Fikra: Jurnal IImiah Keislaman, Vol. 17, No. 2, Juli-Desember, 2018 (324 338)

Tim Penyusun Kamus Pembinaan dan Pengembangan Bahasa. 1999. Kamus Besar Bahasa Indonesia, Jakarta: Balai Pustaka.

Umam, Khairul, A. Ahyar Aminudin,. 1998. Ushul Fiqih II, Bandung: Pustaka Setia

Ya'cub, Ali Mustafa. 1997. Sejarah dan Metode Dakwah Nabi, Jakarta: Pustaka Firdaus. 